\title{
Revisiting Understanding of The Whistleblowing Concept In The Context of Indonesia
}

\author{
Ilham Nurhidayat ${ }^{1}$ \\ Bevaola Kusumasari ${ }^{2}$
}

\begin{abstract}
The conduct of this study came in the backdrop of thinking of the need for opening a discussion for a more comprehensive and contextual concept of whistleblowing for Indonesia from the vantage point of existing theoretical perspectives, regulations and practices. There is a lot of misunderstanding and bias about the concept of whistleblowing in public and private organizations in Indonesia. This study is largely based on previous literature and observation of the implementation of whistleblowing system (WBS) in several institutions that the author considered credible enough to be best practices. The study used descriptive qualitative approach and used various reference sources that were drawn from library research. This research has produced several formulations. First, the synonym or equivalent phrase in the Indonesian language for the term whistleblower is Pengungkap dugaan kecurangan, (revealer of alleged fraud) and Pengungkap dugaan pelanggaraan (revealer of alleged violation) or Pengungkap dugaan perbuatan tidak benar (wrongdoing) (revealer of alleged wrongdoing). Secondly, the most appropriate equivalence to the phrase whistleblowing system (WBS) in the context of Indonesia is "Sistem Pengungkapan Dugaan Pelanggaran" (alleged violation disclosure system). Third, the object of the report or complaints of whistleblowing (wrongdoing) is classifying into seventeen types of behavior that are in turn categorized into seven groups. WBS development and implementation in a number of government and private sector institutions emphasize seven key points. Research findings fill a mainstream research gap on whistleblowing in Indonesia, which has for long been plagued by misunderstanding between WBS and complaints handling system that is evident in several institutions and government agencies in Indonesia. The expectation is that research results will make some contribution to government policy making in the realm of whistleblowing system by providing a definition that is in line with the initial conception of the concept of whistleblowing. That way, this research is expected to contribute to the development of a more effective policy and WBS that not only protects the whistleblower but also pays attention ethics, culture, and local context in Indonesia which are different from the countries where the concept of whistleblowing had its origins.
\end{abstract}

\section{Keywords:}

government; whistleblowing system; wrongdoing.

\section{Introduction}

Despite the fact that whistleblowing behavior has for long been considered a normal social phenomenon or become mainstream in the United States of America (Magnus dan Viswesvaran, 2005), it is still a concept that is difficult to understand (Adler dan Daniels, 1992). Davis (1996) found evidence of paradox in understanding whistleblowing among previous researchers, which strengthens the above argument. Besides, Davis (1996) contends that inconsistency abounds on whistleblowing between theory and reality (practice).

\footnotetext{
${ }^{1}$ Department of Public Policy and Management, Faculty of Social and Political Sciences, Universitas Gadjah Mada. Email: ilham.nurhidayat@mail.ugm.ac.id and ilhamnurhidayat@gmail.com

${ }^{2}$ Department of Public Policy and Management, Faculty of Social and Political Sciences, Universitas Gadjah Mada. Email: bevaola@yahoo.com and bevaola@ugm.ac.id
} 
Davis goes further to explore in detail other theories on whistleblowing, and tests and confirms such theories using actual classic whistleblowing cases. Davis found difference between systematic understanding and whistleblowing action in the people's mind. The phenomenon of difference in understanding is also prevalent in Indonesia. There is a lot of misunderstanding and bias about the concept of whistleblowing in public and private organizations. The purpose of this article is to open a discussion for a more comprehensive and contextual concept of whistleblowing that takes into consideration theoretical perspective and existing regulatory framework and practices in Indonesia.

\section{Methods}

This research used qualitative descriptive method to understand the concept of whistleblowing and whistleblowing application system conditions in a number of public institutions in Indonesia. Data was collected using library research, which was supplemented by a strategic review of documents on the implementation of whistleblowing system (WBS) in a number of organizations in Indonesia.

\section{Definition and Concept of Whistleblowing}

Previous researchers have formulated several definitions of the behavior of whistleblowing, which were aimed at enhancing understanding of the concept. According to King (1997), Tavakoli et al. (2003), Brennan (2007) and Price Waterhouse Coopers (2011), the most commonly used definition in empirical research is one that was formulated by Miceli and Near, which is as follows:

\footnotetext{
Whistleblowing is defined as "disclosure by organization members (former or current) of illegal or illegitimate practices under the control of their employers, to person or organizations that may be
}

able to effect action." (Miceli and Near, 1984: 689)

The above definition is very general which makes developments to the original concept possible, which in turn leaves room for many variations (Miceli et al. 2001). Lewis (2011) expanded on the definition which Miceli and Near formulated, by clarifying that whistleblowing action or disclosing a case means disclosure of information by employees or former employees about malpractices and illegal or negligent activities at the place of work.

The concept of whistleblowing has been based on ethics right from its inception. Ethical values, which form the foundation of whistleblowing behavior include honesty, protection of public interests, and rejection of violation of rules of behavior and ethical codes. The Encyclopedic Dictionary of Public Administration strengthens the argument that the concept of whistleblowing as behavior must be underpinned by ethics. This is evident in the following description of the concept:

\begin{abstract}
"the term whistleblowing refers to the ethical act or action of reporting a violation or a dysfunction within organization, for the purpose of avoiding wrongdoing or serious abuse." ${ }^{\prime 3}$ (Peterson, 2003)
\end{abstract}

To obtain a more comprehensive understanding of the concept or key aspects of whistleblowing, the following section presents a compilation of definitions used by previous research on the topic. To have an in-depth understanding of the concept and key aspects of whistleblowing, the researcher conducted content analysis by identifying keywords that were used in definitions of the concept in research. Identifying process was not limited to mapping the general elements such

\footnotetext{
${ }^{3}$ http://www.dictionnaire.enap.ca/dictionnaire/docs/ definitions/definitions_anglais/whistleblowing.pdf
} 
Table 1.

Compilation of Definitions of Whistleblowing Gleaned from Previous Researchers

\begin{tabular}{ll}
\hline \multicolumn{1}{c}{ Name of the Researcher } & \multicolumn{1}{c}{ Keywords in the definition used } \\
\hline Petersen \& Farell, 1986: 4-5 & - a special form of dissent \\
& - a member or former member wrongdoing, illegality, or actions that threaten \\
Elliston et al. 1985:3-15 in Johnson & - to make information public \\
and Kraft, 1990:850-851 & - public record \\
& - possible or actual important "wrongdoing” \\
& - is not a journalist or ordinary citizen \\
Jubb, 1999: 78 & - a deliberate non-obligatory act of disclosure \\
& - privileged access \\
Marthin, 1996 in Nan, 2011 & - non-trivial \\
Boatright, 2000 & - Significant moral problem \\
Brenkert, 2010 & - non-public information \\
& - Internally or externally \\
& - Capable and willing to stop or prevent \\
Hers, 2002 & - Substantive or serious \\
& - Wrongdoing \\
& - non-trivial activities \\
& - wrongdoing \\
\hline
\end{tabular}

Source: Review of Literature (research)

as whistleblowing activities, whistleblower, content that is reported and recipients of the information, but also identifies several viewpoints and emphasis in each definition. Table 1 depicts a compilation of definitions of whistleblowing as follows:

Some of the definitions that were formulated by previous researchers on the concept of whistleblowing were mapped in accordance with keywords used in describing whistleblowing practices. A review of several definitions in the previous research led to the formulation of a comprehensive definition of whistleblowing that appears below:

"Whistleblowing is an act of releasing information that meets the following criteria: based on action: done intentionally and voluntaliry; type and nature of information: nonpublic information (information, which has not been disclosed prior to the action hence not known to the public), wrongdoing, which occurs or has the potential to occur, a significantly moral problem, substantial, serious, and valuable information, journalists or ordinary members of society; channels used in reporting: use internal or external reporting channels, making use of special communication channels that not normally used; recipient of the information: an entity or individual with the capacity and will to stop or prevent the malpractice to occur; and output: takes the form of information or public records." (Source: research results, 2014-2016).

\section{Definition and Concept of Whistleblower}

A whistleblower (alternatively written as whistle-blower or whistle blower $)^{4}$ is an individual who discloses any type of information or activity considered illegal, unethical, or wrong in private or public organization (Vandekerckhove and Lewis, 2010). Information about suspicious wrongdoing which the whistleblower reports or discloses can be categorized into several types that include violation of company policy, laws, regulations, or gander to public interests or national security, and fraudulent activities and

\footnotetext{
${ }^{4}$ Company, Houghton Mifflin Harcourt Publishing. . www.ahdictionary.com.
} 
corruption (Near and Miceli, 1985). MerriamWebster ${ }^{5}$ defines the term whistleblower from another as an individual who submits a report to the police, journalists and other entities about something (for example a crime) that is concealed.

In practice, a whistleblower often understood to refer to a witness or an individual who provides information or serve as a witness in a case that involve criminal behavior to law enforcement in criminal proceedings. Nonetheless, an individual can only become a whistleblower, if the witness he or she conveys or submits meets the following basis criteria:

"The first criteria, whistleblower conveys or submits a report to authority that is vested with the power, mass media or public. Secondly, a whistleblower is an 'insider' in the organization, who discloses violation of company policy or regulations and crime that has occurred in the organization that is the place of work. To that end, a whistleblower knows very well that suspicious violation or committing of crime in the place of work being perpetrated by a certain organized group, in the company, public institution, or government institution. The report which the whistleblower conveys or submits, is an actual event or is very well known by the whistleblower. Thus, the report is not fabrication or character assassination." (Semendawai et al. 2011: 1-2).

Based on the criteria that were formulated by Semendawai et al.(2011), a whistleblower must have evidence and sufficient information about the misappropriation, fraud or wrongdoing being reported.

\footnotetext{
${ }^{5}$ Whistleblower is a person who tells police, reporters, etc., about something (such as a crime) that has been kept secret; a corporate whistle-blower [=a person who works for a corporation and tells people about the corporation's illegal activities]. Retrieved October, 1, 2017 from http:// www.learnersdictionary.com/definition/whistle-blower.
}

In general, whistleblowers are classified into two broad categories: internal and external whistleblower (Rowe in Lavinia Hall ed, 1993:105-119). Internal whistleblower is an employee of a company or institution who reports an act that violates laws to other employees or superiors in the same company. Meanwhile, an external whistleblower is an employee of an organization who conveys a report of wrongdoing in the organization to external organizations.

To gain deeper understanding of whistleblower, the researcher conducted a compilation of several definitions of whistleblower as formulated or used by previous researchers on the topic. Table 2 presents a summary of the compilation. Some of the definitions do not only contain general elements of a whistleblower, object that is reported and recipient of information, but also have mapping of differences in viewpoints and emphasis in each definition.

Whistleblower was mapped using several keywords that were gleaned from definitions of whistleblower as formulated and used by previous researchers. This research uses a comprehensive definition of whistleblower that is derived from a review of literature on definitions that were used in previous research. The definition that is used follows:

"Whistleblower is an individual who is motivated by morality, voluntarily, and does not tolerate illegal activities, negligence, or misuse and conveys the information to the public or the institution or to the relevant representative. An analogy to a whistleblower is a natural voice in an organization is there to scrutinize any possibilities of negligence or wrongdoing, which may endanger public interests." (Source: Research results)

\section{Object of Whistleblowing Reporting}

Based on previous research, wrongdoing 
Table 2.

Compilation of definitions of Whistleblower from Previous Pesearchers

\begin{tabular}{|c|c|}
\hline Name of Researcher & Keywords \\
\hline $\begin{array}{l}\text { Whistleblower is sound an alarm from within the very organization in } \\
\text { which they work, aiming to spotlight neglect or abuses that threaten the } \\
\text { public interest (Bok, 1980: 277) } \\
\text { a whistleblower is an employee or officer of any institution, profit or non- } \\
\text { profit, private or public, who believes either that he/she has been ordered } \\
\text { to perform some act or he/she has obtained knowledge that the institution } \\
\text { is engaged in activities which (a) are believed to cause unnecessary harm } \\
\text { to third parties, (b) are in violation of human rights or (c) run counter to } \\
\text { the defined purposes of the institution and who inform the public of this } \\
\text { fact. (Bowie, 1982: 142) }\end{array}$ & $\begin{array}{l}\text { - Sound an alarm } \\
\text { - Neglect or abuse } \\
\text { - Public interest } \\
\text { - No longer silently tolerate } \\
\text { - Reveal those abuses }\end{array}$ \\
\hline $\begin{array}{l}\text {..... are morally required to reveal what you know to the public (or to a } \\
\text { suitable agent or representative of it, when: (C1) What you will reveal } \\
\text { derives from your work for an organization (C2) You are a voluntary } \\
\text { member of that organization (C3) You believe that the organization, } \\
\text { although legitimate, is engaged in a serious moral wrong (C4) You believe } \\
\text { that your work for that organization will contribute (more or less directly) } \\
\text { to the wrong if (but only if) you do not publicly reveal what you know } \\
\text { (C5) You are justified in beliefs (C3) and (C4), (C6) Beliefs (C3) and (C4) are } \\
\text { true. (Davis, 2003) }\end{array}$ & $\begin{array}{l}\text { - Ordered to perform or obtained } \\
\text { knowledge about wrongdoing } \\
\text { - Inform the public }\end{array}$ \\
\hline $\begin{array}{l}\text { People who no longer silently tolerate illegal activities, maladministration } \\
\text { or danger to humans, the environment and the economy, but reveal those } \\
\text { abuses within or outside their business, their company, their organization } \\
\text { or their bureaucracy (Strack, 2011) }\end{array}$ & $\begin{array}{l}\text { - Morally required to reveal } \\
\text { - To the public (or to a suitable } \\
\text { agent or representative of it) } \\
\text { - Voluntary member } \\
\text { - Serious moral wrong }\end{array}$ \\
\hline
\end{tabular}

Source: Results from literature review

is one of the objects of the reporting process or information that the whistleblowers discloses. Some previous research such as Near et al. (2004), Kaplan et al. $(2009,2011)$ categorizes types of behavior that fall into wrongdoing. Near, et al.(2004) breaks up wrongdoing into seventeen types of behavior that in turn are classified into seven categories.

The first category is stealing, which consists of six types of mistakes,_that include: 1) stealing government money, 2) stealing governments assets, 3) receive a bribe, 4) exploit the police or position for personal interest, 5) give an abnormal advantage to a contractor, and 6) violations perpetrared by office employees. The second category is waste, and consists of three types of wrongdoing that include: 1) profligacy because a person who does not quality to become beneficiary of service becomes a beneficiary, 2) profligacy manifested in poor project management, and 3) profligacy of assets of the organization. Third category, relates to mismanagement, which consists of two types of wrongdoing, which include: 1) act of management to conceal poor performance and 2) management makes mistakes in formulating project performance projections. The fourth category related to safety, and consists of two types of wrongdoing that include: 1) unsafe or dangerous products or products that does not fulfill all the requirements; 2) unsafe working conditions. The fifth category covers problems of sexual harassment and consists of two types of wrongdoing that include: 1) seducing or making lewd gestures with the intention of inviting one for sex that is not desired ; 2) making oral and physical sexual contract. Category six relates to discrimination, which is based on race, gender, and so on. Category seven, relates to serious violations of laws.

In accordance with the categorization of wrongdoing by Near, et al. (2004), corrupt behavior falls into the first category. To that end, in many definitions of whistleblowing, 
corruption is specifically classified as one of the objects of reporting action that is often disclosed through whistleblowing. Based on researchers, experts, national and international institutions, corruption has many definitions. Nonetheless, there is yet no consensus on the standard definition of what corruption means. This is attributable to the fact that characteristics and the nature of corruption, especially the type that involves individuals are difficult to detect because they occur in opaque conditions that not easy for others to see.

World Bank (1996) definition of corruption is the act of giving, receiving or offering, directly or indirectly, in anything that is valuable, to influence unfairly the decision or action from another person or entity. Essentially, corruption is misuse of power for personal gain. Based on Black's Law Dictionary (Garner, 1999: 348), universally, corruption, denotes depravity, perversion, or taint; an impairment of integrity, virtue, or moral principles, especially the impairment of a public official's duties by bribery).

Tanzi (1998) also formulated a definition of corruption which has neutral meaning that is intentional noncompliance, which occurs in the context of a bargaining transaction, or intentional diversion of corruption allegation to another person and obtain benefits for oneself with the collusion of the related individual. Tanzi (1998) describes the definition of the intention of an individual to commit corruption as a characteristic of corruption as the level of potential and separable from actual act of corruption. According to theory of analogy (Statler et al., 2008), the duo concept which underpins the element of intention and action of an individual go hand in hand with motivation and behavior in the discipline of organizational behavior (Dahl, 2005), or between strategy formulation and strategy implementation in the discipline of strategic management (Barney and Hesterley, 2008).

In a survey on the definition of corruption which was conducted by Redlawsk and McCann (2005), identified several aspects. First, an activity which contains ambiguity but in general is unlawful or deviation from normal work in an organization. Secondly, behavior which is done in order to obtain economics benefits or status that may include engaging in bribery, nepotism, misappropriation (budget) or favoritism.

In the context of public sector organizations, Heidenheimer (1970, 2002) prefers to use the phrase political corruption or public-office-center corruption. Political corruption is a violation that is perpetrated by a member of public apparatus that gives legal favors with the compensation of bribes, nepotism to group interests to the detriment of public interests or an action that involves the embezzlement of public funds.

Rabl and Kuhlman (2008) give a detailed grouping of some of the elements of dimensions of the behavior of a corrupt individual. The dimensions include: a) existence of exchange between two or more people with respect to benefits, with joint agreement in a voluntary manner; b) contains violation or deviation from organizational norms and ethics or public law; c) contains abuse of power, authority or position or knowledge that one is entrusted with to obtain benefits that serve one's interests ; d) does not contain victim as the third party; e) existence of secrecy consequent upon the formation of close relationships or underground community. In accordance with the above understanding, Rabl and Kuhlman (2008) were able to merge between intention and action of perpetrating corruption.

\section{Redefinition of the concept of Whistleblowing in Indonesian Context}

Initially, in Indonesia, the whistleblower was not a technical term or standard term in law that was known by all sections of society. The term whistleblower was introduced and even became a buzzword and "trending topic" as well as center of public attention when 
Khairiansyah Salman, who was at the time an auditor of Supreme Auditory agency (BPK RI), conveyed a report of efforts by a commissioner of the general election commission to bribe him to the corruption eradication agency. The bribe was animated at influencing auditing service which Khairiansyah was conducted on the commissioner. In 2005 Khairiansyah received the integrity award from Transparency International, in Berlin Germany for his integrity and courage to disclose bribery and misappropriation that plagued the National general elections commission.

In fact public interest in the term whistleblower increased when the national witness and victims protection agency (LPSK), and Law mafia eradication unit under the Ministry of Law and Human rights reached an understanding on granting reductions in jail terms and parole for whistleblowers who express readiness to collaborate with law enforcement, popularly referred to as "justice colaborator". The requirements which the prospective justice collaborator must fulfill include the individual must not be the main actor of the crime. In reality, whistleblower are not always individuals who were involved in perpetrating the crime. Whistleblower can be an active employee, former employee, menial worker, member of organization who voluntarily is motivated by ethical obligation to report action that $\mathrm{s}(\mathrm{he})$ considers violates laws to authorities. Whistleblower must have high moral values and courage to report acts of wrongdoing. In practice, a whistleblower is often considered having equivalence to an internal witness or an individual who observes and reports abuse and misappropriation for public interest, or observes something that is concealed or discloses information for public interest.

The formation of the corruption eradication commission (KPK) as an anticorruption agency was based on Law No. 30/ 2002, which also formulated a definition of whistleblower. A whistleblower, according to
$\mathrm{KPK}$, is an individual who reports an act that indicates corruption crime which is perpetrated in an organization where the individual works, and has access to adequate information on indications of the alleged corruption. ${ }^{6}$

Besides KPK, other institutions such as LPSK and the Mahkamah Agung (MA) also formulated their respective definitions of a whistleblower. In article 1, Law on protecting witnessed and victims, stipulates that a witness ${ }^{7}$ is an individual who can provide information that can help in investigations, indictment, and inspection in the court in a criminal to which the individual in question was a witness or experienced. Meanwhile, MA defines a whistleblower as stipulated in the MA circulation letter No. 4/2011, as an individual who has knowledge and reports a certain criminal act and was not involved or among the perpetrators of the crime that is reported.

Based on several definitions above, there are stark differences between the meaning of whistleblower and several terms with meaning that is relatively similar in Indonesian language such as reporter of a crime, informant, or witness in general. A review of history of the term indicates that whistleblower was initially introduced and used in circles of law or the law on public servants. Thus, in light of the above discussion and formulations of various definitions of the term in the previous section, this research summarizes the criteria that an individual must fulfill to become a whistleblower:

1. An employeein a governmental organization or private organization.

2. Has conviction that is wrongdoing in the organization where he or she works or there is potential for wrongdoing to occur.

3. Wrongdoing can cause loss to the

\footnotetext{
${ }^{6}$ Retrieved October 1, 2017 from https://kws.kpk.go.id/

7 The Law on protection of Witnesses and victims does not have a special term for a whistleblower. The term whistleblower in the Law is equated to the reporting witness
} 
organization and can have wide ranging impact on the public and public interests.

4. Information that is disclosed is that which is allowed under existing laws and regulations.

5. Disclosure of information relates to rights and duties of an individual and is done using the right media.

The word whistleblower is an English word. The Word has synonyms and translations in Indonesian language. One of the equivalent phrases that is very popular is "peniup peluit", literary blower of the whistle. The term blower of the whistle is used to describe decisive action of members of the police in England who blow the whistle whenever they witness the perpetration of a criminal act. A whitle is blown to inform other members of law enforcement and the general public about the impending danger to their safety (Dasgupta and, 2010). The term is also commonly used as a reflection of the work of a referee in a football match or other competitions. The referee blows the whistle to signal violation of rules of the game (Usman and Mujahidin, 2005). The term blower of the whistle is also used to describe action of individuals from within the organization both public officials and politicians who have the courage to disclose or voice the existence of signs of deviations, fraud or violations in the organization where they serve. Without such disclosure acts of wrongdoing may remain unknown to the general public.

Besides the term blower of the whistle, there are several synonyms of whistleblower in Indonesian language. The list includes for example pembisik or literary whisperer, pengungkap aib or revealer of secrets, saksi pelapor or reporting witness, pelapor fakta or fact reporter, and pelapor tindak pidana or crime

\footnotetext{
8 The term whistleblower comes from the phrase "blow the whistle" which refers to a whistle being blown by a police officer or a referee to indicate an activity that is illegal or a foul. Retrieved October 11, 2017 from http:// en.wikipedia.org.wiki/Whistleblower.
}

act reporter. Nonetheless, the above terms do neither sufficiently represent nor adequately equivalent to the term whistleblower. This is because of several fundamental considerations, which among others include:

1. The term blower of the whistle or peniup peluit is too mundane to embody the meaning of disclosure in either an oral or written sentence.

2. The term pembisik or whisperer is too general and not specific enough according to the Indonesian language dictionary 1) an individual who whispers something to another person; 2) a person who is tasked the duty to whisper what other actors must say in a parody.

3. The term pengungkap aib or divulger of taboo as used in wikipedia Indonesia (it has been modified and replaced by the term pelapor pelanggaran or reporter of violation) is considered not appropriate if related to revelation of other taboos such as family secrets which has no relation to the term 'whistleblower'.

4. The term saksi pelapor or reporting witness and the term saksi or witness which is used by LPSK in the book titled "Memahami Whistleblower" understanding whistleblower is in contravention with principles anonymity (secrecy of the identity of the individual making the report), which generally applies in the context of whistleblowing system (WBS), despite the fact that the application of the principle of anonymity is optional. This shows that in principle, WBS can be likened to a process of sending a letter without the identity of the sender which has been accorded an enhancement in both its grade of trust and level of accountability. 
5. The term pelapor fakta or literary facts reporter as used by LPSK is also wanting and not appropriate given the reality that anybody who reports facts can become a whistleblower. Many other professions are by nature and occupation, report facts. This includes journalists, correspondents, or news presenters.

The term pelapor tindak pidana or literary crime act reporter, which Mahkamah Agung (MA) uses is debatable. This specifically has much to do with the phrase tindak pidana or criminal act. The term has the potential to eliminate possibility of violations that fall outside the category of criminal acts. Besides, absence of the term alleged or allegation in the definition is contrary to the principle of innocent until proven guilty in the reporting process which must be preserved during the reporting and investigation process. The phrase ".... and not part of the perpetrator of the crime that is being reported" in the definition of whistleblower that MA proposed raises a question. How about individual who reporter crimes in which they have been involved, but after the act they realize their mistakes and change their minds, and subsequently report the criminal act?

Based on a comparative analysis of meaning of various synonyms of the term whistleblower in the Indonesian language above, the author considers the mostappropriate phrase in the Indonesian language to the term whistleblower that this research uses is pengungkap dugaan kecurangan literary (revealer of alleged misappropriation), pengungkap dugaan pelanggaraan (revealer of alleged violation) or pengungkap dugaan perbuatan tidak benar (wrongdoing) (revealer of alleged wrongdoing). The phrase this research uses corroborates with the phrase pengungkap dugaan pelanggaraan (revealer of violation), which
Iskandar (2013) ${ }^{9}$ proposed. The two terms are more comprehensive because they are not confined to criminal law domain, and take into account the principle of innocence until proven guilty. To that end, this research uses the term whistleblowing of alleged violation to refer to the Whistleblowing System (WBS) reporting mechanism.

The formulation of the definition 'whistleblowing of alleged violation' as an equivalence of the term whistleblower in the local Indonesian context, which subsequently this research uses goes as follows:

\begin{abstract}
"An Individual who reveals alleged corruption, fraud or wrongdoing, violation, dishonesty, or an act that flouts the law that occurs in an organization. Alleged violation can take the form of flouting existing laws, regulations, rules, and or pose threat to public interest such as manipulation, violating existing laws and regulations on health, safety, and corruption. Revealing or disclosing alleged violation can be both internal (reporting the alleged violator who is employed or part of the same organization as the individual making the report) or external (reporting an alleged violator to regulators, law enforcement agencies, mass media, or group that is relevant or has keen interest in the issue that is reported."
\end{abstract}

\section{Developments in the Implementation of Whistleblowing System (WBS) in Indonesia}

To date the euphoria and immense attention toward eradicating corruption is till focused on dealing with violators of the crime. To that end, prevention and proactive detection of the potential for corruption before it occurs, remain areas that have not received as much attention. This makes prevention and early detection areas that need special

\footnotetext{
${ }^{9} \mathrm{http}$ //ferli.net/padanan-istilah-whistleblower-adalahpengungkap-dugaan-pelanggaran/
} 
attention. The last few years have witnessed an increase and improvement in whistleblowing culture and recognition of the important role and contribution of whistleblowers to the disclosure of information to the public about alleged violation, flouting of laws and ethics. In other words, whistleblowing culture has emerged and developed in various government and private institutions. This points to an improvement and recognition of the importance of organizational culture in preventing the existence of conditions that foster violation and perpetration of corruption from occurring in organizations.

The trauma and dilemma which a whistleblower face can be minimized through the development of a strong reporting and protection system for whistleblowers that guarantee legal protection. Whistleblower needs legal protection guarantee and /or other forms of special protection. Unfortunately, the Law No.13/2006 on protection of witnessed and victims does not contain clauses of provisions that guarantee provision of protection to whistleblowers (LPSK, 2011).

Nonetheless, the government continues to develop a whistleblowing system (WBS) within the government bureaucracy in Indonesia. One good example is the whistleblowing or complaints system which the corruption eradication agency (KPK) has developed. KPK as an official institution with authority and power to reduce and eradicate corruption in Indonesia, has developed and continues to strengthen internet-based complaints called “KPK-Whistleblower System." Other government institutions such as Government procurements policy agency (LKPP) has specifically developed a Whistleblowing System in the procurement of goods and services which tailored toward handling all complaints that relate to allegations of deviations and violations in the procurement of government goods and services that occur in the place where the whistleblower serves.
Moreover, other various institutions in the government and private sector, have also developed and implemented WBSthemed complaints management systems in the organization. Several state owned enterprises for example PT Telkom Indonesia, PERTAMINA, and Garuda Indonesia have also developed and implemented whistleblowing system, which makes it possible for an individual to report any signs that point to alleged fraud, violation of laws and ethics, misconduct or mismanagement that occur in the organization. In an attempt to reduce risk of abusing authority and power, the private sector has developed and implemented channels or avenues that are themed Whistleblowing System (WBS) for conveying complaints in the organization.

The outcome of an analysis of the implementation of WBS in a number of institutions in the government and private sector led to several important points. First, the individual who makes the report is not a member of the organization or an insider of the organization where the wrongdoing occurs. Secondly, some of the information that is reported does not constitute an indication or case that falls into the category of wrongdoing. Thirdly, the reports that made are not accompanied or supported by sufficient or strong evidence of the alleged violation or some of the evidence does not support the alleged violation. Fourthly, webbased or (internet based) channels, facilities, or media are used to collect and convey complaints to the institutions that receive them, some use hotline, email, telephone or social media. Fifth, most complaints mechanisms are uphold the anonymity principle. Sixthly, the verification team conducts information management. Seventh, information is analyzed and forwarded to those vested with authority to make follow up of the case that is reported. 
Aspects of Legal Protection for the Whistleblower

Protection of the whistleblower is an interesting issue in Indonesia. In the $13^{\text {th }}$ International Conference on Anticorruption which was held in Athens, Greece, produced a number of recommendations that relate to the law on protecting whistleblowers. The conference categorized the protection into international requirements or conditions, logical consequences of the responsibility and special requirements. Some of the highlights of the points include: 1) protection of whistleblower is an international requirement, for example under the United Nations Convention against Corruption (2003) and the Council of Europe Civil Law Convention on Corruption (1999), both of which are "hard laws"; 2) fair assumption that protection of the whistleblower must be a logical consequence of the responsibility or duties of a public official, or private employee (or certain category of employees) dand every citizen who reports a criminal act to the police or prosecution; and 3) protection of whistleblower is a special requirement, which is different from other anti-corruption programs especially for countries that are experiencing structural corruption or serious organized crime, that is protection of witnesses, justice collaborator, victims and experts (this is another international requirement) .

In Indonesia, whistleblower is explicitly defined in the Government regulation (PP) No. $71 / 2000$ on the procedures of implementing Public Participation and Appreciation within the context of preventing and eradicating Corruption. A whistleblower is an individual who gives/conveys information to law enforcement agencies or commission on the existence of corruption but not in the capacity of a complainant. Whistleblower is often understood as a reporting witness or an individual who makes a report or gives witness about an alleged criminal act to law enforcement agencies in the criminal justice process. To that end, it is imperative that a whistleblower must be receive guaranteed legal protection or special sufficient protection in other forms.

In the context of public participation in eradicating corruption and providing legal protection for the whistleblower, Indonesia has a number of laws to that effect. Such laws include: 1) Government regulation No. 71/2000 on the Implementation of public participation extending appreciation in the context of eradicating and preventing corruption; 2) Article 15, Law No. 30/2002 on the Corruption eradication agency, which stipulates that the commission provides protection to witnesses or those individual who make reports or provide information on corruption; and 3) Law No. 13/2006 on The protection of witnesses and victims. Regrettably, to this day, there is no provision in Law No. 13/2006 on the Protection of Witnesses and Victims that explicitly gives special protection to individuals who convey complains or reports about alleged corruption or violation or whistleblower (LPSK, 2011).

\section{Conclusion}

This research has produced several formulations. First, the synonym or equivalent phrase in the Indonesian language for the term whistleblower is Pengungkap dugaan kecurangan (revealer of alleged fraud) and Pengungkap dugaan pelanggaraan (revealer of alleged violation) or Pengungkap dugaan perbuatan tidak benar (wrongdoing) (revealer of alleged wrongdoing). Secondly, the most appropriate equivalence to the phrase Whistleblowing System (WBS) in the context of Indonesia is Sistem Pengungkapan Dugaan Pelanggaran (alleged violation disclosure system). Third, the object of the report or complaints of whistleblowing (wrongdoing) is classified into seventeen types of behavior that are in turn categoized into seven groups. Results findings also underscore the reality that WBS development and implementation in a number 
of government and private sector institutions emphasize seven key points.

\section{References}

Adler, J. N., Daniels, M. (1992). Managing the whistleblowing employee. The Labor Lawyer, $8(1), 19-70$.

Boatright, J.R. (2000). Ethics and the conduct of business. Upper Saddle River, NJ: PrenticeHall.

Bok, S. (1980). Whistleblowing and Profesional Responsibilities. Ethics Teaching in Higher Education. 11: 277-295.

Bowie, N.E. (1982). Business Ethics. Englewood Cliff: Prentice Hall.

Brennan, N., Kelly, J. (2007). A study of whistleblowing among trainee auditors. The British Accounting Review, 39(1), 61-87. doi:10.1016/jbar.2006.12.002

Brenkert, G.G., (2010). Whistleblowing, moral integrity and organizational ethics. In Brenkert, G.G., \& Beauchamp, T.L (Eds.) The Oxford handbook of business ethics (pp. 563-601). UK: Oxford University Press.

Dahl, R. (1957). The concept of power. Behavioral Science, 2(3), 202-203.

Dasgupta, S., \& Kesharwani, A. (2010). Whistleblowing: a survey of literature. The IUP Journal of Corporate Governance, IX(4), 1-14.

Davis, M. (1996). Some paradoxes of whistleblowing. Business $\mathcal{E}$ Professional Ethics Journal, 15(1), 3-19. doi: 10.5840/ bpej19961517

Davis, M. (2003). Some paradoxes of whistleblowing. In W.H. Shaw (Eds.), Ethics at work (pp. 85-99). UK: Oxford University Press.

Elliston, F.A. (1985). Whistleblowing: managing dissent in the workplace. New York: Praeger.

Garner, B. A. (1999). Black's Law Dictionary. USA: West Publishing.

Heidenheimer, A. J. (2002). Perspectives on the perception of corruption. In A.J. Heidenheimer, \& M. Johnson (Eds.),
Political corruption: context and concepts. New Brunswick, New Jersey: Transaction Publisher

Hersh, M.A. (2002). Whistleblowers-Heroes or Traitors?: individual and collective responsibility for ethical behaviour. Annual Reviews in Control, 26, 243-262.

Johnson, R. A., \& Kraft, M. F. (1990). Bureaucratic whistleblowing and policy change. The Western Political Quartely, 43(4), 849-874.

Jubb, P., (1999). Whistleblowing: a restrictive definition and interpretation. Journal of Business Ethics, 21(1), 77-94.

Kaplan, S. E., Pany, K., Samuels, J. A., \& Zhang, J. (2009). An examination of the effects of procedural safeguards on intention to anonymous report fraud. AUDITING: $A$ Journal of Practice \& Theory, 28(2), 273-288. doi: 10.2308/aud.2009.28.2.273

Kaplan, S.E., Pany, K., \& Samuels, J. A. (2010). The effects of social confrontation on individual's intention to internally report fraud. Behavioral Resarch in Accounting, 22(2), 51-67. doi: 10.2308/bria.2010.22.2.51

King, G. I. (1997). The effects of interpersonal closeness and issue seriousness on blowing the whistle. Journal of Business Communication, 34(4), 419-36. doi: 10.1177/002194369703400406

Lembaga Perlindungan Saksi dan Korban (LPSK). (2011). Pandangan awal tahun 2011 kondisi perlindungan saksi dan korban di Indonesia (Catatan Akhir Tahun). Jakarta: LPSK.

Lewis, D. (2011). Whistleblowing in a changing legal climate: Is it to revisit our approach to trust and loyalty at the workplace?. Buiness Ethics: A European Review, 20(1), 71-87.

Mesmer-Magnus, J. R., \& Viswesvaran, C. (2005). Whistleblowing in organizations: An examination of correlates of whistleblowing intentions, actions, and retaliation. Journal of Business Ethics, 62(3), 277-297.

Martin, B. (1996). Critics of pesticides: whistleblowing or suppresion of dissent?. Philosophy and Social Action, 22(3), 33-55. 
Miceli, M. P., Scotter, J. R., Near, J. P., \& Rehg, M. T. (2001). Individual differences and whistle-blowing. Academy of Management Proceedings, 2001(1). doi: 10.5465/ apbpp.2001.6133834

Near, J.P., \& Miceli, M. P. (1985). Organizational dissidence: The case of whistle-blowing. Journal of Business Ethics, 4(1), 1-16. doi:10.1007/bf00382668

Near, J. P., Rehg, M. T., Scotter, J. R., \& Miceli, M. P. (2004). Does Type of Wrongdoing Affect the Whistle-Blowing Process. Business Ethics Quarterly, 14(2), 219-242. doi: 10.5840/ beq200414210

Peterson, J. C., \& Farell, D. (1986). Whistleblowing: Ethical and Legal Issues in Expressing Dissent. Dubuque, IA: Kendall/Hunt Publishing Company.

Peterson, S. A. (2003). Public Policy. In J. Rabin (Eds.), Encyclopedia of Public Administration and Public Policy. New York \& Basel: Marcel Dekker.

PriceWaterhouseCoopers. (2011). Global economic crime survey 2011. Retrieved December 2, 2011 from http://www.pwc. com/en_GX/gx/economic-crimesurvey/ assets/GECS_GLOBAL_REPORT.pdf.

Rabl, T., \& Kuhlmann, T. (2008). Understanding corruption in organizations-development and empirical assesment of an action model. Journal of Business Ethic, 82, 477-495.

Redlaws, D.P., \& McCann, D.P. (2005). Popular interpretation of 'CORRUPTION' and their Partisan Consequences. Political Behavior, 27(3).
Rowe, M. (1993). Option and choice for conflict resolution in the workplace. In L. Hall (Eds.), Negotiation: Strategies for Mutual Gain (pp. 105-119). USA: Sage Publications, Inc. Semendawai, A. H. (2011). Memahami Whistleblower. Jakarta: LPSK Indonesia.

Statler, M., Jacobs, C. D., \& Roos, J. (2008). Performing strategy: analogical reasoning as strategic practice. Scandinavian Journal of Management, 24(2), 133-144. doi: 10.1016/ jscaman.2007.11.006

Strarck, K. (2001). What's right/wrong with journalism ethics research?. Journalism Studies, 2(1), 133-152.

Tanzi, V. (1998). Corruption around the world: causes, consequences, scope, and cures. Staff Papers - International Monetary Fund, 45(4), 559-594.

Tavakoli, A., J.P. Keenan \& B. Crnjak-Karanovic. (2003). Culture and whistleblowing an empirical study of Croatian and United States managers utilizing Hofstede's cultural dimensions. Journal of Business Ethics, 43(1), 49.

Usman, A., \& Mujahidin, A. M. (n.d) [Whistleblower dalam perdebatan pemberantasan tindak pidana korupsi]. Unpublished raw data.

Vandekerckhove, W., \& Lewis, D. (2012). The content of whistleblowing procedures: a critical review of recent official guidelines. Journal of Business Ethics, 108(2), 253-264. 